\title{
Multiple Gq-Coupled Receptors Converge on a Common Protein Synthesis-Dependent Long-Term Depression That Is Affected in Fragile X Syndrome Mental Retardation
}

\author{
Lenora J. Volk, Brad E. Pfeiffer, Jay R. Gibson, and Kimberly M. Huber \\ Department of Neuroscience, University of Texas Southwestern Medical Center, Dallas, Texas 75390
}

\begin{abstract}
Gq-coupled, $\mathrm{M}_{1}$ muscarinic acetylcholine receptors (mAChRs) facilitate hippocampal learning, memory, and synaptic plasticity. $\mathrm{M}_{1}$ mAChRs induce long-term synaptic depression (LTD), but little is known about the underlying mechanisms of mAChR-dependent LTD and its link to cognitive function. Here, we demonstrate that chemical activation of $\mathrm{M}_{1} \mathrm{mAChRs}$ induces LTD in hippocampal area CA1, which relies on rapid protein synthesis, as well as the extracellular signal-regulated kinase and mammalian target of rapamycin translational activation pathways. Synaptic stimulation of $\mathrm{M}_{1} \mathrm{mAChRs}$, alone, or together with the Gq-coupled glutamate receptors (mGluRs), also results in protein synthesis-dependent LTD. New proteins maintain $\mathrm{mAChR}$-dependent LTD through a persistent decrease in surface AMPA receptors. mAChRs stimulate translation of the RNA-binding protein, Fragile X mental retardation protein (FMRP) and FMRP target mRNAs. In mice without FMRP ( Fmr1 knock-out), a model for human Fragile X syndrome mental retardation (FXS), both mGluRand mAChR-dependent protein synthesis and LTD are affected. Our results reveal that multiple Gq-coupled receptors converge on a common protein synthesis-dependent LTD mechanism, which is aberrant in FXS. These findings suggest novel therapeutic strategies for FXS in the form of mAChR antagonists.
\end{abstract}

Key words: muscarinic acetylcholine; Gq coupled; metabotropic glutamate; hippocampus; Fragile X syndrome; long-term depression; protein synthesis

\section{Introduction}

Activity of Gq-coupled, muscarinic acetylcholine receptors regulates hippocampal-dependent learning and memory consolidation (for review, see Hasselmo, 2006). Consequently, loss of cholinergic innervation to the hippocampus during Alzheimer's disease $(\mathrm{AD})$ is thought to contribute to the cognitive deficits observed in AD (Kesner et al., 1989; Caccamo et al., 2006). $\mathrm{M}_{1}$ muscarinic acetylcholine receptors (mAChRs), the primary Gqcoupled mAChRs in hippocampus, contribute to hippocampaldependent memory, and $\mathrm{M}_{1}$ agonists reverse the cognitive deficits in AD mouse models (Anagnostaras et al., 2003; Caccamo et al., 2006). $M_{1}$ mAChRs may facilitate memory and cognition in part through modulation or induction of plasticity at excitatory synapses (Anagnostaras et al., 2003; Shinoe et al., 2005). Understanding the mechanisms by which mAChRs mediate hippocampal-dependent synaptic plasticity will provide insight into cholinergic-dependent cognitive enhancement.

Received May 17, 2007; revised Aug. 29, 2007; accepted Sept. 10, 2007.

This work was supported by National Institutes of Health Grants 1F31NS050992 (B.E.P.) and NS045711 (K.M.H.), the McKnight Foundation and FRAXA Research Foundation (K.M.H.), and the National Science Foundation (L.J.V.). K.M.H. is a Southwestern Medical Foundation endowed scholar in biomedical research. We thank Maggie Waung for help with the AMPAR trafficking experiments in dissociated neuron cultures and members of the Huber laboratory and Ege Kavalali for helpful discussions and comments on this manuscript.

Correspondence should be addressed to Kimberly Huber, Department of Neuroscience, University of Texas Southwestern Medical Center, 5323 Harry Hines Boulevard, Dallas, TX 75390-9111. E-mail: Kimberly.Huber@ UTSouthwestern.edu.

DOI:10.1523/JNEUROSCI.2266-07.2007

Copyright $\odot 2007$ Society for Neuroscience $\quad$ 0270-6474/07/2711624-11\$15.00/0
Activation of $\mathrm{M}_{1}$ mAChRs induces long-term depression (LTD) of excitatory synaptic transmission (mAChR-LTD) in CA1 and neocortex (Kirkwood et al., 1999; Massey et al., 2001; Choi et al., 2005; Jo et al., 2006; Scheiderer et al., 2006), but little is known of the cellular mechanisms underlying mAChRdependent LTD or how it is related to LTD induced by other Gq-coupled receptors. The cholinergic agonist carbachol (CCh) stimulates new protein synthesis in CA1 dendrites, suggesting a mechanism by which $\mathrm{mAChRs}$ establish long-lasting changes at synapses (Feig and Lipton, 1993). A form of LTD induced by pharmacological activation of Gq-coupled group 1 metabotropic glutamate receptors (mGluRs) has been characterized previously and relies on rapid, dendritic protein synthesis (Palmer et al., 1997; Fitzjohn et al., 1999; Huber et al., 2000; Fitzjohn et al., 2001). Paired pulses of low-frequency synaptic stimulation (1 Hz; PP-LFS) delivered to Schaffer collateral axons also induces protein synthesis-dependent LTD (Huber et al., 2000). Although initial studies observed that PP-LFS and other synaptic stimulation paradigms induce an mGluR-dependent LTD in CA1 (Bolshakov and Siegelbaum, 1994; Oliet et al., 1997; Kemp and Bashir, 1999), more recent work has failed to confirm a role for group 1 mGluRs in LTD induced specifically with PP-LFS (Volk et al., 2006). The importance of protein synthesis-dependent LTD to human cognition is highlighted by the finding that it is selectively enhanced in the mouse model of human Fragile $\mathrm{X}$ syndrome mental retardation, Fmrl knock-out (KO) mice (Huber et al., 2002; Koekkoek et al., 2005; Hou et al., 2006). Fragile X 
mental retardation protein (FMRP), the product of Fmr1, is an RNA-binding protein that functions as a regulator of translation (for review, see Garber et al., 2006). It is unknown whether FMRP specifically regulates plasticity through group 1 mGluRs or generally affects protein synthesis-dependent plasticity in response to other neurotransmitters.

Here, we find that synaptic or pharmacological activation of $\mathrm{M}_{1}$ mAChRs induces LTD in hippocampal area CA1, which requires rapid protein synthesis, and we identify a role for these newly synthesized proteins in AMPA receptor (AMPAR) trafficking. To examine whether FMRP generally regulates Gq- and protein synthesis-dependent plasticity, we investigated $\mathrm{mAChR}$ dependent LTD in Fmr1 KO mice. Our results indicate that the Gq-coupled acetylcholine and glutamate receptors converge on a common protein synthesis-dependent LTD mechanism, which is abnormal in Fragile X syndrome (FXS). These results provide a link between altered cholinergic-dependent synaptic plasticity and cognitive dysfunction, as well as suggest novel therapeutic strategies for FXS, mental retardation, and related autistic disorders (Bear et al., 2004).

\section{Materials and Methods}

Drugs. Carbamoylcholine chloride (CCh), TTX, pirenzepine, anisomycin, atropine, picrotoxin (Sigma, St. Louis, MO), U0126 (1,4-diamino2,3-dicyano-1,4-bis[2-amino-phenylthio]butadiene), 2-methyl-6(phenylethynyl)-pyridine (MPEP), ( $S)$ - $(+)$ - $\alpha$-amino-4-carboxy-2methylbenzeneacetic acid (LY367385) (Tocris Bioscience, Ellisville, $\mathrm{MO}$ ), and rapamycin (Calbiochem, San Diego, CA) were prepared as stocks in water, DMSO (U0126, rapamycin, actinomycin D, picrotoxin), or equimolar $\mathrm{NaOH}$ (LY367385), aliquoted and frozen for no more than 10 d. D,L-AP-5 (Tocris Bioscience) was prepared fresh in artificial CSF (ACSF). N-ethyl bromide quaternary salt (QX-314) Cl- (Alomone Labs, Jerusalem, Israel) was dissolved directly into the internal solution.

Electrophysiology. Hippocampal slices were prepared from postnatal day 25 (P25) to P45 Long Evans hooded rats (Charles River, Wilmington, $\mathrm{MA}$ ) or the C57BL/6 congenic strain of Fmrl KO and wild-type mice (obtained from Dr. Steve Warren, Emory University, Atlanta, GA). Rats or mice were anesthetized with the barbiturate pentobarbital $(50 \mathrm{mg} / \mathrm{kg}$ ) and decapitated soon after the disappearance of corneal reflexes. For whole-cell recordings, rats were transcardially perfused with ice-cold dissection buffer for $\sim 1$ min before decapitation. The brain was removed, and the hippocampus was dissected and sliced at $400 \mu \mathrm{M}(300 \mu \mathrm{M}$ for intracellular recordings) in slushed (partially frozen) dissection buffer containing the following (in mM): $2.6 \mathrm{KCl}, 1.25 \mathrm{NaH}_{2} \mathrm{PO}_{4}, 26 \mathrm{NaHCO}_{3}$, $0.5 \mathrm{CaCl}_{2}, 5 \mathrm{MgCl}_{2}, 212$ sucrose, and 10 dextrose, using a vibratome (VT 1000S; Leica, Nussloch, Germany). CA3 was cut off slices immediately after slicing to prevent any CCh-induced oscillations of CA3 neurons from contaminating evoked synaptic responses in CA1 (Scheiderer et al., 2006). The slices were transferred into a reservoir chamber filled with ACSF containing the following (in mM): $124 \mathrm{NaCl}, 5 \mathrm{KCl}, 1.25 \mathrm{NaH}_{2} \mathrm{PO}_{4}$, $26 \mathrm{NaHCO}_{3}, 2 \mathrm{CaCl}_{2}, 1 \mathrm{MgCl}_{2}$, and 10 dextrose for field recordings or $119 \mathrm{NaCl}, 2.5 \mathrm{KCl}, 1 \mathrm{NaH}_{2} \mathrm{PO}_{4}, 26 \mathrm{NaHCO}_{3}, 2 \mathrm{CaCl}_{2}, 1 \mathrm{MgCl}_{2}$, and 11 dextrose (290-300 mOsm) for intracellular recordings. Slices were allowed to recover for $2-5 \mathrm{~h}$ at $30^{\circ} \mathrm{C}$. ACSF and dissection buffer were continuously aerated with $95 \% \mathrm{O}_{2} / 5 \% \mathrm{CO}_{2}$.

For intracellular recording, slices were transferred to a submerged recording chamber (Warner Instruments, Hamden, CT), maintained at $30^{\circ} \mathrm{C}$ and perfused continuously with ASCF at a rate of $2.5-3 \mathrm{ml} / \mathrm{min}$. Picrotoxin $(20 \mu \mathrm{M})$ was added to the ACSF immediately before transferring slices to the recording chamber. Whole-cell voltage-clamp recordings were obtained from CA1 pyramidal neurons in slices visualized using IR-DIC optics (Gibson et al., 2006). Neurons were clamped at -60 $\mathrm{mV}$ through whole-cell recording pipettes $(\sim 3-7 \mathrm{M} \Omega)$ filled with an intracellular solution containing the following (in mM): $130 \mathrm{~K}$-gluconate, $6 \mathrm{KCl}, 3 \mathrm{NaCl}, 10$ HEPES, 10 sucrose, 2 QX-314, 0.2 EGTA, 4 ATP-Mg, 0.3 GTP-Na, 14 phosphocreatine-Tris, pH 7.2, 290-310 mOsm. EPSCs were evoked every $10 \mathrm{~s}$ using a single bipolar electrode placed in stratum radiatum of area CA1 (along the Schaffer collaterals) 50-200 $\mu \mathrm{m}$ from the recorded neurons with monophasic current pulses $(5-25 \mu \mathrm{A}, 200$ $\mu \mathrm{s})$. Series resistance (SR) and input resistance were measured in voltage clamp with a $400 \mathrm{~ms},-10 \mathrm{mV}$ step from a $-60 \mathrm{mV}$ holding potential (filtered at $30 \mathrm{kHz}$, sampled at $50 \mathrm{kHz}$ ). Series resistance did not change significantly over the course of the experiment for the cells used (paired Student's $t$ test, $p=0.2$; baseline SR vs SR at $60 \mathrm{~min}$ ). Average SR values for the cells used ranged from 16 to $34 \mathrm{M} \Omega$. Initial input resistance values ranged from 126 to $282 \mathrm{M} \Omega$. Data were not corrected for junction potential.

For extracellular recordings, slices were placed in a submersion recording chamber (BSC-ZT; Harvard Apparatus, Holliston, MA), perfused at $3 \mathrm{ml} / \mathrm{min}$, and field EPSPs (fEPSPs) were recorded using electrodes (1-2 M $\Omega$ ) filled with ACSF and placed in stratum radiatum of area CA1. Field EPSPs were evoked by monophasic stimulation (200 $\mu \mathrm{s} \mathrm{du-}$ ration) of Schaffer collateral/commissural afferents with a concentric bipolar tungsten stimulating electrode (FHC, Bowdoinham, ME). Baseline presynaptic stimulation was delivered once every $30 \mathrm{~s}$ in rat (see Figs. 1-4) and once every $5 \mathrm{~s}$ in mice (see Fig. 6) (Scheiderer et al., 2006) using a stimulation intensity $(10-30 \mu \mathrm{A})$ yielding $50-60 \%$ of the maximal response. The initial slope of the FP was used to measure stability of synaptic responses and quantify the magnitude of LTD. LTD was elicited by application of $50 \mu \mathrm{M}$ CCh for $10 \mathrm{~min}$ as indicated. Synaptically induced LTD was induced using paired pulses (50 ms interstimulus interval) of low-frequency $(1 \mathrm{~Hz})$ stimulation (PP-LFS) for 15 or $20 \mathrm{~min}$ as indicated (1800 or 2400 pulses) (Huber et al., 2000). Note that synaptic responses are not collected during PP-LFS, so no data points are plotted during this time. Theta-burst stimulation $(\theta)$ consisted of 10 bursts at 5 $\mathrm{Hz}$, each burst containing four pulses at $100 \mathrm{~Hz}$, given four times at $10 \mathrm{~s}$. Group data were analyzed as follows: (1) the initial slope (fEPSPs) or amplitude (EPSCs; 1 min moving average) was expressed as a percentage of the baseline average, (2) the time scale in each experiment was converted to time from the onset of CCh or PP-LFS, and (3) the timematched, normalized data were averaged across experiments and expressed in the figures as the means $( \pm$ SEM). LTD was calculated as a 5 min average of the normalized fEPSP slope values $1 \mathrm{~h}$ after CCh or PP-LFS. The effects of all pharmacological treatments on LTD were evaluated by comparing interleaved control and treated slices. For LTD experiments, significant differences were determined by a Student's independent $t$ test versus control measured at $1 \mathrm{~h}$ after LTD induction. Probability values of $p<0.05$ were considered to represent significant differences.

Dissociated culture and immunocytochemistry. Dissociated CA3-CA1 hippocampal cultures were prepared from P0-P2 rats using modified, previously published protocols (Brewer et al., 1993). Neurons were plated at a density of 250 neurons $/ \mathrm{mm}^{2}$ on poly-D-lysine/laminin or matrigel-coated coverslips. Experiments were performed at $18-22 \mathrm{~d}$ in vitro. All AMPA receptor internalization and surface expression results were confirmed with the experimenter blind to the treatment condition. For AMPA receptor internalization assays: live cultures were pretreated with $1 \mu \mathrm{M}$ TTX for $15 \mathrm{~min}$, labeled with anti-GluR $\mathrm{N}_{1} \mathrm{~N}$-terminal antibody (1:10; Calbiochem, La Jolla, CA) for $15 \mathrm{~min}$, followed by treatment with $50 \mu \mathrm{M}$ CCh or water ( $\pm 75 \mathrm{~nm}$ pirenzepine) for $10 \mathrm{~min}$. Internalization was allowed to proceed for $15 \mathrm{~min}$ after washout of CCh. Cells were then fixed in $4 \% \mathrm{PFA} / 4 \%$ sucrose for $15 \mathrm{~min}$ at $37^{\circ} \mathrm{C}$. Surface $\mathrm{GluR}_{1}$ was blocked with unlabeled $2^{\circ}$ donkey anti-rabbit antibody $[1 \mathrm{~h}$, room temperature (RT)], followed by permeabilization with $0.2 \%$ Triton-X (10 min, RT). Cells were blocked with TBS/ $10 \%$ goat serum $(1 \mathrm{~h}, \mathrm{RT})$ and then treated with Alexa Fluor $2^{\circ}$ antibody (1:300, 1 h, RT; Invitrogen, Eugene, OR) to visualize internalized $\mathrm{GluR}_{1}$. For surface $\mathrm{GluR}_{1}$ experiments, cells were pretreated with $1 \mu \mathrm{M}$ TTX ( \pm anisomycin where indicated) for $20 \mathrm{~min}$ followed by treatment with $50 \mu \mathrm{M}$ CCh or water for 10 min. Cells were then fixed (as described above) but not permeabilized 10 or $60 \mathrm{~min}$ after washout of CCh. Cells were blocked in TBS/10\% goat serum $(1 \mathrm{~h}, \mathrm{RT})$, treated with anti-GluR $\mathrm{N}_{1}$-terminal antibody $(1: 50 ; 1 \mathrm{~h}$, RT) washed, and then treated with Alexa Fluor $2^{\circ}$ antibody. For $M_{1}$ $\mathrm{mAChR}$ staining, cultures were fixed as described above and treated with anti-M $\mathrm{M}_{1} \mathrm{mAChR}$ antibody (1:100; Millipore, Billerica, MA).

Fluorescence was detected using a Nikon (Tokyo, Japan) TE2000 in- 
verted microscope equipped with a cooled CCD camera (Roper CoolSnapHQ). Images were analyzed and quantitated using MetaMorph software (Universal Imaging, West Chester, PA). For synaptic staining, immunoreactive puncta are defined as discrete points along a dendrite (within $50 \mu \mathrm{m}$ from the soma) with fluorescence intensity at least twice the background staining of a region adjacent to the dendrite. For all group data, the average number of puncta was determined for all control cells within each culture (1-2 coverslips, 5-20 cells per condition per culture). The number of puncta in each control and treated cell was then normalized to this value. Averages \pm SEM are plotted, and $n$ (number of cells) is on each bar $\left({ }^{*} p<0.05 ;{ }^{* *} p<0.01\right)$.

Western blotting. Hippocampal slices were prepared as for electrophysiology experiments. After a 2-3 h recovery period in ACSF, slices were maintained in a static incubation chamber in ACSF at $30^{\circ} \mathrm{C}$ and aerated with $95 \% \mathrm{O}_{2} / 5 \%$ $\mathrm{CO}_{2}$. Slices were treated with $\mathrm{CCh}(10 \mathrm{~min})$ or ACSF (control). In experiments where anisomycin was used, slices were preincubated with anisomycin (30-60 $\mathrm{min})$ before treatment. Slices were frozen on dry ice immediately after treatment and stored at $-80^{\circ} \mathrm{C}$ until processing ( $3 \mathrm{~d}$ or less). In a subset of experiments (see Figs. $1 F, 6 F$ ) CA1 was microdissected on wet ice in slushed ACSF before freezing. Quantitative Western blots were performed on slice homogenates using antibodies against FMRP (1: 2500; Millipore IC3), EF1 $\alpha$ (1:10,000; Upstate Biotechnology, Lake Placid, NY), $\alpha \mathrm{Ca}^{2+}$ / calmodulin-dependent protein kinase II ( $\alpha$ CaMKII) (1:200,000; Santa Cruz Biotechnology, Santa Cruz, CA), phospho-p70 S6 kinase (Thr389; 1:1000; Cell Signaling Technology, Beverly, MA), or phospho-ERK (Thr202/ Tyr204; 1:1000; Cell Signaling Technology) as described previously (Gallagher et al., 2004; Volk et al., 2006). Homogenates were also probed for total ERK (1:2000; Cell Signaling Technology) or vasoline-containing peptide (VCP; 1:10,000; gift from Dr. Thomas Südhof, University of Texas Southwestern Medical Center, Dallas, TX) as loading controls. Data are presented as percentage control (all samples have within animal controls). Significant differences were determined by a Student's independent $t$ test versus control (see Fig. $1 F$ ) or by a one-sample $t$ test as percentage control (see Fig. $6 E, F)$.

\section{Results}

The cholinergic agonist carbachol induces protein synthesisdependent LTD in hippocampal area CA1

Previous work has demonstrated that the general cholinergic agonist CCh $(50 \mu \mathrm{M} ; 10 \mathrm{~min})$ induces long-term depression of extracellularly recorded population EPSPs or fEPSPs (Kirkwood et al., 1999; Massey et al., 2001; Lee et al., 2005; Scheiderer et al., 2006). To determine whether this protocol induces LTD of EPSCs and whether this is associated with changes in passive membrane properties, we performed whole-cell voltage clamp (at -60 $\mathrm{mV}$ ) recordings of CA1 pyramidal neurons in rat acute hippocampal slices. After a stable baseline of EPSC amplitudes was established, CCh application ( $50 \mu \mathrm{M} ; 10 \mathrm{~min}$ ) induced a robust, acute depression followed by a long-lasting depression of EPSCs
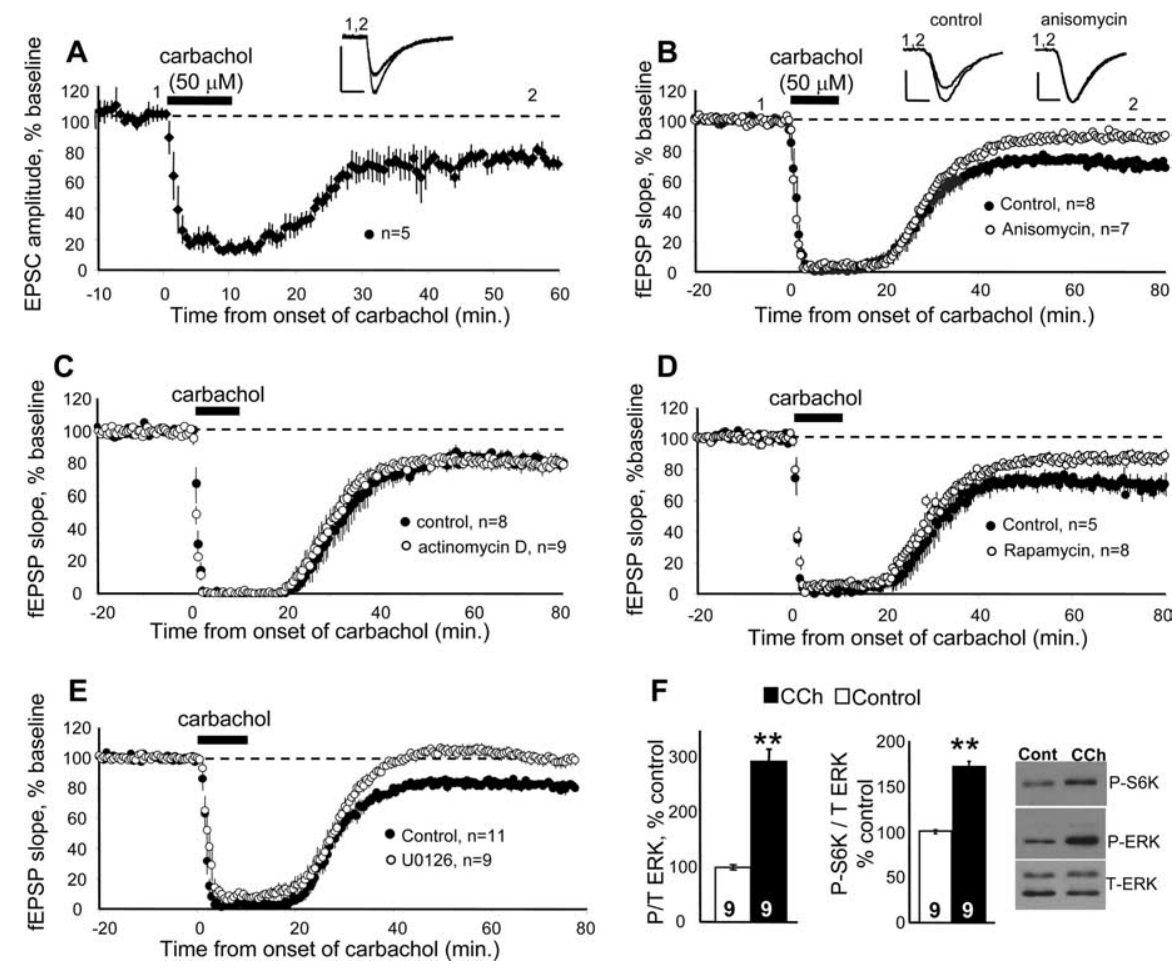

Figure 1. Muscarinic acetylcholine receptor-induced long-term synaptic depression requires protein synthesis, ERK, and mTOR values of EPSC or average initial slope values of fEPSPs normalized to the pre-CCh baseline. All drugs except CCh were present in

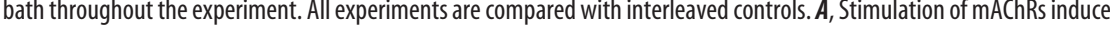
clamped at $-60 \mathrm{mV}$ for the duration of the experiment). Calibration: $100 \mathrm{pA}, 10 \mathrm{~ms}$. B, The protein synthesis inhibitor anisomycin $(25 \mu \mathrm{m}$ ) significantly reduces CCh-induced LTD (control, $70 \pm 2 \%$; anisomycin, $87 \pm 3 \% ; p<0.001$ ). LTD is quantified as a 5 min average taken $1 \mathrm{~h}$ after CCh washout, and all statistical comparisons are made at this time point (see Materials and Methods). Inset, fEPSP waveforms (average of $4-6$ traces) from a representative experiment are taken at the time points indicated on the graph DMSO), $81 \pm 4 \%$; actinomycin $D, 80 \pm 3 \% ; p=0.8]$. D. The mTOR antagonist rapamycin (20 nм) reduces CCh-induced LTD (0.1\% DMSO), $69 \pm 5 \%$; rapamycin, $87 \pm 3 \% ; p<0.01)$. $\boldsymbol{E}$, The MEK inhibitor U0126 (20 $\mu \mathrm{m}$ ) blocks CCh-induced LTD $p=0.7]$. F Acute rat hippocampal slices (CA3 removed) were treated +10 min with $50 \mu \mathrm{M}$ (Ch. After treatment CA1 was microdissected on ice, and samples were immediately frozen on dry ice and processed for Western blotting. Right panel, Representative Western blots. P-S6K, phospho-p70 S6 kinase; P-ERK, phospho ERK; T-ERK, total ERK. Middle panel, Quantification of CCh-induced activation of p70 S6 kinase at the rapamycin-sensitive site (Thr389) (P-S6K/T-ERK, \% control) in nine slices (control, $100 \pm 2 \%$; CCh, $\left.171 \pm 6 \% ;{ }^{* *} p<0.001\right)$. Left panel, Quantification of CCh-induced ERK activation (P-ERK/T-ERK, \% control) in nine slices (control, $100 \pm 5 \%$; CCh, $293 \pm 23 \% ;{ }^{* *} p<0.001$ ).

(Fig. 1A). CCh also induced a trend toward a long-term increase in input resistance (baseline $R_{\mathrm{m}}, 190 \pm 28 \mathrm{M} \Omega, 60 \mathrm{~min}$ after CCh; $\left.R_{\mathrm{m}}, 244 \pm 39 \mathrm{M} \Omega, p=0.09\right)$ consistent with the findings that $\mathrm{M}_{1}$ $\mathrm{mAChRs}$ reduce a number of membrane currents (Dutar and Nicoll, 1988) .

Pharmacological activation of $\mathrm{mAChRs}$ induces protein synthesis in CA1 dendrites (Feig and Lipton, 1993). To determine whether newly synthesized proteins are required for mAChRdependent LTD in CA1, acute rat hippocampal slices were preincubated (20-40 min) in the protein synthesis inhibitor anisomycin $(25 \mu \mathrm{M})$. Consistent with previous studies, LTD was induced in interleaved control slices with the general cholinergic agonist CCh (50 $\mu \mathrm{M} ; 10 \mathrm{~min}$ ) (Kirkwood et al., 1999; Massey et al., 2001; Lee et al., 2005; Scheiderer et al., 2006). We refer to this as CChLTD. Anisomycin did not affect the acute synaptic depression observed with CCh but dramatically reduced the magnitude of LTD (Fig. $1 B$ ). Similarly, preincubation of slices with a mecha- 

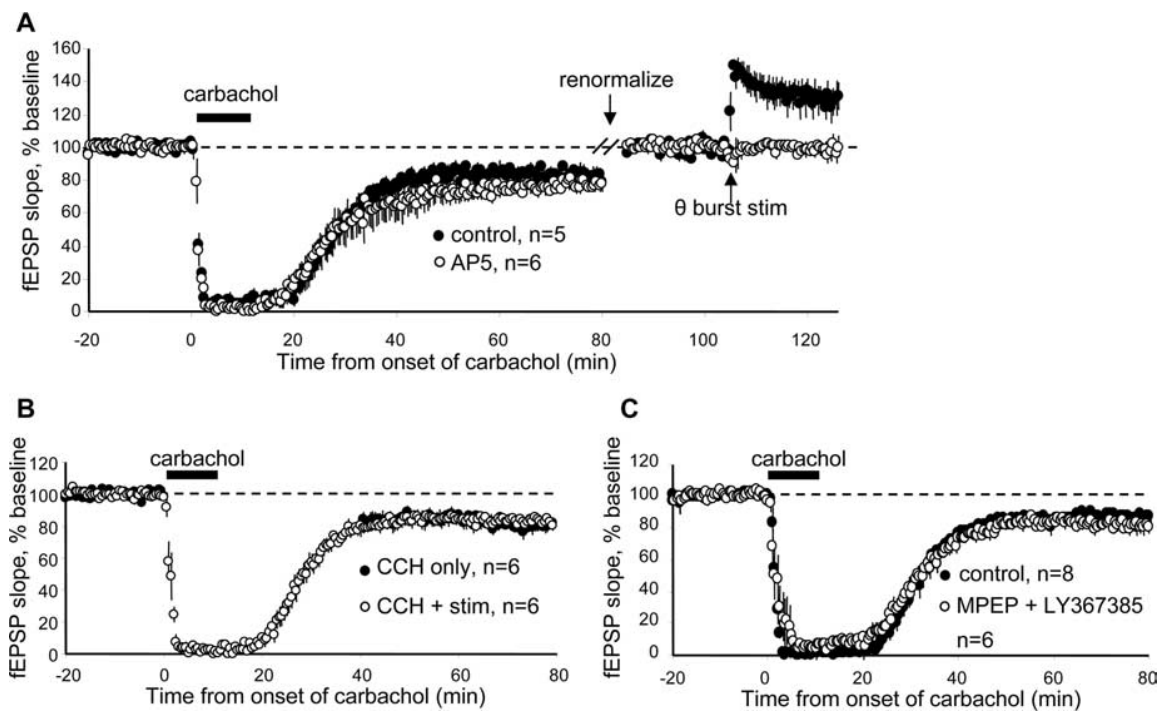

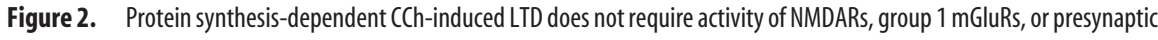
stimulation. $\boldsymbol{A}$, Preincubation of slices in the NMDA receptor antagonist, D,L-AP-5 (100 $\mu \mathrm{m})$ before CCh had no effect on LTD (control, $82 \pm 5 \% ; A P-5,77 \pm 2 \% ; p=0.3$ ). AP-5 was effective in blocking LTP induction with a theta-burst stimulation $(\theta ; \uparrow$ ) delivered after CCh-LTD induction (measured 25 min after theta burst; control, $129 \pm 7 \%$; AP-5 = 99 $\pm 1 \% ; \theta$ in AP-5, $p=0.77$ vs baseline; $\theta$ in control, $p=0.01$ vs baseline). fEPSP slope values are renormalized to pre-theta baseline. $\boldsymbol{B}$, Cessation of presynaptic stimulation immediately before and for 30 min after CCh application (CCh only) had no effect on LTD magnitude compared with slices in the same recording chamber, which received continuous stimulation during $\mathrm{CCh}$ (CCh + stim) (CCh + stim, $83 \pm 2 \%$; CCh no stim, $80 \pm 3 \% ; p=0.4$.). C, Blockade of mGluR5 and mGluR 1 with MPEP (10 $\mu \mathrm{M})$ and LY367385 (100 $\mu \mathrm{M})$, respectively, had no effect on LTD induced with CCh (control, $87 \pm 1$; MPEP + LY, $81 \pm 4 \% ; p=0.2$ ) .

nistically different protein synthesis inhibitor, cycloheximide $(60$ $\mu \mathrm{M}$ ), blocked CCh-LTD (LTD measured 75 min after CCh washout; control, $78 \pm 3 \%, n=6$; cycloheximide, $94 \pm 4 \% ; p=0.001$, control vs cycloheximide; $p=0.1$, cycloheximide baseline vs 75 min after CCh washout). These results reveal that newly synthesized proteins are required for mAChRs to establish LTD. To determine whether CCh-LTD requires transcription of new mRNAs, we pretreated slices in the transcription inhibitor actinomycin $\mathrm{D}(25 \mu \mathrm{M})$. Interleaved control slices were treated with vehicle ( $0.1 \%$ DMSO). CCh-LTD is unaffected by actinomycin D (Fig. 1C), suggesting that protein synthesis from pre-existing mRNAs is sufficient to support CCh-LTD for at least $1 \mathrm{~h}$.

Translation in neurons is regulated through two major signaling pathways, the mammalian target of rapamycin (mTOR) and extracellular signal-regulated kinase (ERK) pathways, via phosphorylation of factors known to stimulate translation initiation such as eukaryotic initiation factor $4 \mathrm{E}$ (eIF4E), $4 \mathrm{E}$ binding protein (4EBP), and ribosomal S6 protein (for review, see Dufner and Thomas, 1999; Kelleher et al., 2004a; Klann and Dever, 2004). To determine whether the mTOR or ERK translational regulatory pathways were required for CCh-LTD, slices were pretreated with either an inhibitor of mTOR (20 nM rapamycin) or the upstream activating kinase of ERK, mitogen-activated protein/ERK kinase (MEK; $20 \mu \mathrm{M}$ U0126). Interleaved control slices were incubated in vehicle ( $0.1 \%$ DMSO). Rapamycin reduced the magnitude of CCh-LTD, similar to anisomycin (Fig. 1D), and U0126 completely blocked CCh-LTD (Fig. 1 E). Consistent with a role for ERK and mTOR in CCh-LTD, treatment of hippocampal slices with CCh $(50 \mu \mathrm{M} ; 10 \mathrm{~min})$ induced activation of ERK and mTOR as measured by phosphorylation of ERK (Thr202/ Tyr204) and p70 S6 kinase, at the mTOR site (Thr389) (Fig. 1F) (Dufner and Thomas, 1999; Roberson et al., 1999; Rosenblum et al., 2000; Berkeley et al., 2001). These results strengthen the data that protein synthesis is required for mAChR-dependent LTD and suggest that mAChRs stimulate translation initiation through the ERK and mTOR pathways.

\section{LTD induced by pharmacological stimulation of mAChRs with carbachol is independent of presynaptic activity, NMDA receptors, or group $1 \mathrm{mGluRs}$}

The initial study demonstrating that mAChRs stimulate dendritic protein synthesis observed that synaptic coactivation of NMDA receptors (NMDARs) were also necessary (Feig and Lipton, 1993). More recent studies found that NMDARs are required for mAChR-dependent LTD in some brain regions but not others (Kirkwood et al., 1999; Massey et al., 2001; Jo et al., 2006; Scheiderer et al., 2006). To determine whether NMDARs are required for protein synthesis-dependent CCh-LTD in CA1, slices were preincubated in the NMDAR antagonist D,L-AP-5 (100 $\mu \mathrm{M})$. Normal levels of CCh-LTD were observed in AP-5 compared with interleaved control slices (Fig. $2 A$ ). AP- 5 was active in the slice preparation, because long-term potentiation (LTP) was blocked in all slices subsequent to mAChR-LTD (Fig. 2A, $\theta$-burst). Because CCh -LTD does not require NMDARs, it may also occur independently of synaptic stimulation. To test this, presynaptic stimulation was ceased immediately before CCh application and was not resumed until 30 min after CCh washout (Fig. 2B, CCh no stim). Control slices were placed in the same recording chamber simultaneously but received low-frequency baseline stimulation throughout the experiment $(\mathrm{CCh}+$ stim). Normal levels of CCh-LTD were observed in slices that did not receive presynaptic stimulation (Fig. $2 B)$. Together, these results indicate that CCh-LTD is independent of synaptic NMDAR activation and are consistent with previous work indicating that rapid protein synthesis is required for Gq-dependent LTD but not NMDAR-dependent LTD (Huber et al., 2000; Massey et al., 2001).

The Gq-coupled group 1 mGluRs induce LTD in CA1, which relies on rapid protein synthesis (Huber et al., 2000). Therefore, mAChRs may induce protein synthesis-dependent LTD indirectly by enhancing neuronal excitability, glutamate release, and activation of group 1 mGluRs (Benardo and Prince, 1982). To test whether group $1 \mathrm{mGluR}$ activity was required for CCh-LTD, slices were preincubated in $\mathrm{mGluR}_{1}$ and mGluR5 antagonists, LY367385 $(100 \mu \mathrm{M})$ and MPEP $(10 \mu \mathrm{M})$, which block LTD induced by the group $1 \mathrm{mGluR}$ agonist dihydroxyphenylglycine (DHPG) (Volk et al., 2006). Group 1 mGluR blockade had no effect on CCh-LTD (Fig. 2C). Together, these data suggest that $\mathrm{mAChRs}$ induce protein synthesis-dependent LTD directly through signaling of mAChRs and not through activation of NMDARs or group 1 mGluRs.

\section{Synaptic activation of $\mathrm{M}_{1} \mathrm{mAChRs}$ induces protein synthesis-dependent LTD}

We next determined whether synaptic activation of $M_{1} m A C h R s$ induced protein synthesis-dependent LTD. There are few cholinergic neurons intrinsic to the hippocampus, but extracellular stimulation in CA1 regions of hippocampal slices elicits acetyl- 
choline release from fibers originating from the septal nucleus (Cole and Nicoll, 1983; Frotscher et al., 1986; Schafer et al., 1998; Shinoe et al., 2005). Protein synthesis-dependent LTD can be elicited by electrical stimulation of Schaffer collateral axons using paired pulses of lowfrequency stimulation (50 ms interstimulus interval, $1800-2400$ pulses at $1 \mathrm{~Hz}$; PPLFS) (Huber et al., 2000; Nosyreva and Huber, 2005, 2006). PP-LFS experiments were performed in D,L-AP-5 $(100 \mu \mathrm{M})$ to prevent induction of NMDA receptordependent LTD and isolate G $\alpha$ qdependent LTD. Both the broad range $\mathrm{mAChR}$ antagonist atropine $(5 \mu \mathrm{M})$ (Fig. $3 A$ ) and the $\mathrm{M}_{1}$-selective antagonist pirenzepine (Dorje et al., 1991; Scheiderer et al., 2006) (75 nM) (Fig. 3B) significantly reduced LTD induced with PP-LFS. To implicate endogenous release of acetylcholine in LTD induction, we applied the acetylcholine esterase inhibitor eserine (2 $\mu \mathrm{M})$ during PP-LFS to enhance acetylcholine concentrations in the slice (Fig. 3C). Eserine significantly facilitated the LTD, suggesting that either PP-LFS activates cholinergic terminals or accumulation of basal acetylcholine in the slice is sufficient to enhance LTD. Eserine application alone caused a transient depression but had no long-lasting effects on synaptic transmission (80-85 min average; $98 \pm 2 \% ; p=0.54$ compared with baseline). Antagonism of $\mathrm{M}_{1}$ mAChRs reduces PP-LFS induced LTD but does not completely block it, suggesting involvement of another Gq-coupled receptor, because PP-LFS LTD is completely abolished in G $\alpha \mathrm{q}$ knock-out mice (Kleppisch et al., 2001). Because PP-LFS induced LTD shares a common expression mechanism with LTD induced by pharmacological activation of group I mGluRs, it is likely that group I mGluRs play a role in PP-LFS induced LTD (Huber et al., 2001). Here, we observe that combined application of an $M_{1}$ $\mathrm{mAChR}$ selective antagonist (75 nM pirenzepine; "P") and group I mGluR antagonists $\left(\mathrm{mGluR}_{5}\right.$-specific antagonist MPEP; "M"; $10 \mu \mathrm{M}$ and $\mathrm{mGluR}_{1}$-specific antagonist LY367385; "L", $100 \mu \mathrm{M}$ ) blocks PP-LFS induced LTD (P,M,L) (Fig. 3D). Because PP-LFS induced LTD is unaffected by group $1 \mathrm{mGluR}$ antagonists alone (Volk et al., 2006), but completely blocked by the addition of pirenzepine (Fig. 3D), this indicates that synaptic activation of $\mathrm{M}_{1} \mathrm{mAChRs}$ is sufficient to induce the full level of protein synthesis-dependent LTD. It is only when $M_{1}$ mAChRs are blocked that group $1 \mathrm{mGluRs}$ are required for LTD induction.

To determine whether pharmacological activation of mAChRs and synaptic stimulation of mGluRs and mAChRs (using PP-LFS) use a common expression mechanism, we performed an occlusion experiment (Fig. 4A). Synaptically induced LTD was first saturated by delivering three episodes of PP-LFS followed by CCh application to the slice (AP-5 was present throughout the experiment). Saturation of PP-LFS-induced LTD greatly reduced subsequent CCh-LTD compared with CCh-LTD in naive interleaved control slices (Fig. $4 A$ ). In contrast, saturation of NMDA receptor-dependent LTD (induced with 15 min of $1 \mathrm{~Hz}$ single pulse stimulation or "LFS" in the absence of AP-5 (Dudek and Bear, 1992)) did not occlude induction of LTD with inhibitor eserine (2 $5 \mathrm{~m}, 5 \mathrm{~min}$ before and during PP-LFS) facilitated LTD induced with PP-LFS (15 min) (measured 70 min after Y367385 at $100 \mu \mathrm{M}$ ), "P,M,L" (measured $1 \mathrm{~h}$ after PP-LFS control, $72+4 \%$; "P,M,L", $96+4 \%$; control vs "P,M,L",,$<0.001$

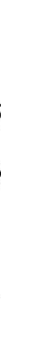

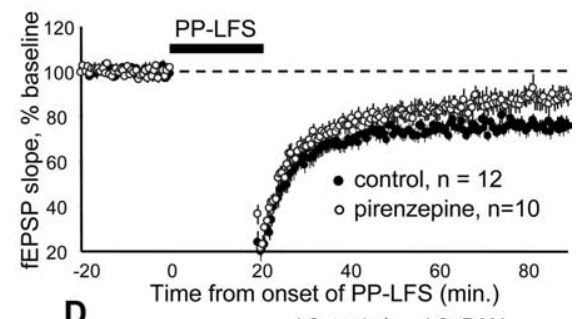

A B

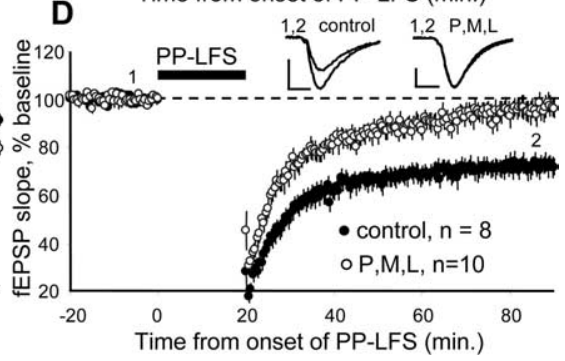

Figure 3. Synaptically induced protein synthesis-dependent LTD requires $M_{1} m A C h R$ activation. All experiments are in the reduces LTD induced synaptically with paired-pulse low-frequency stimulation (PP-LFS, 2 pulses with $50 \mathrm{~ms}$ lockade of the $M_{1}$ subtype of $m A C h R s$ with the $M_{1}$-selective antagonist pirenzepine (75 nM) reduces PP-LFS induced LTD (mea-

- control, $n=10$ - control, $n=10$
- atropine, $n=8$

${ }^{60}{ }^{80}$
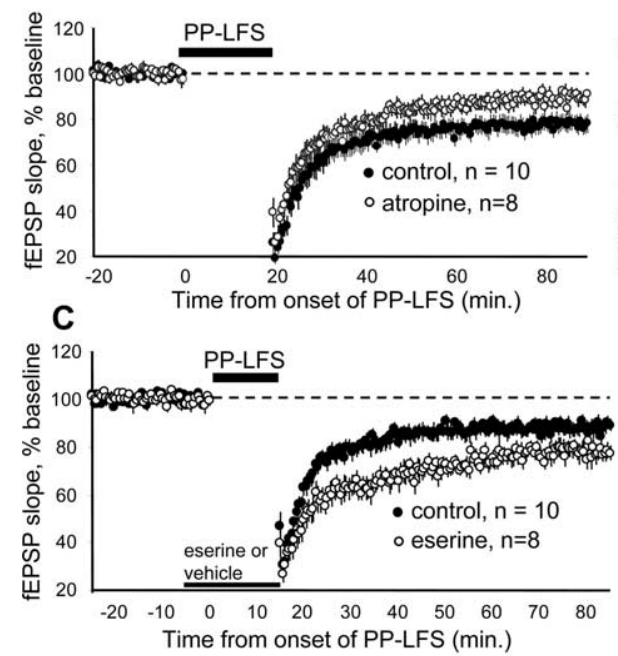

er PP-LFS, control, $78 \pm 3 \%$; atropine, $90 \pm 2 \% ; p=0.01) . B$ B, (1989 
$\mathbf{A}_{1}$

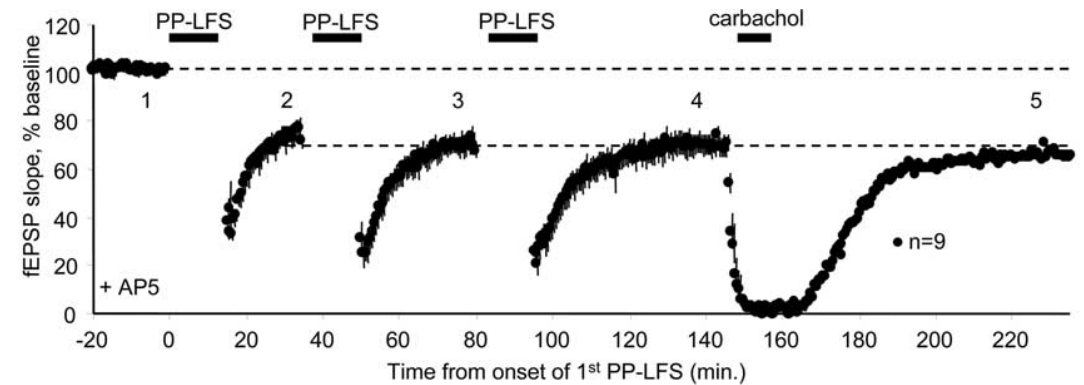

$\mathrm{A}_{2}$
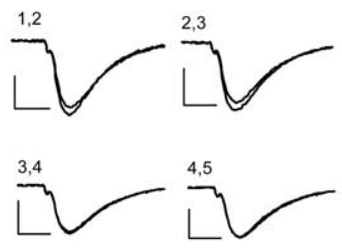

$\mathrm{A}_{3}$

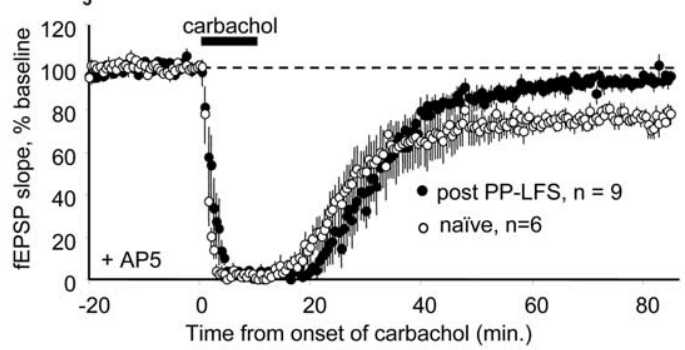

$\mathrm{B}_{1}$

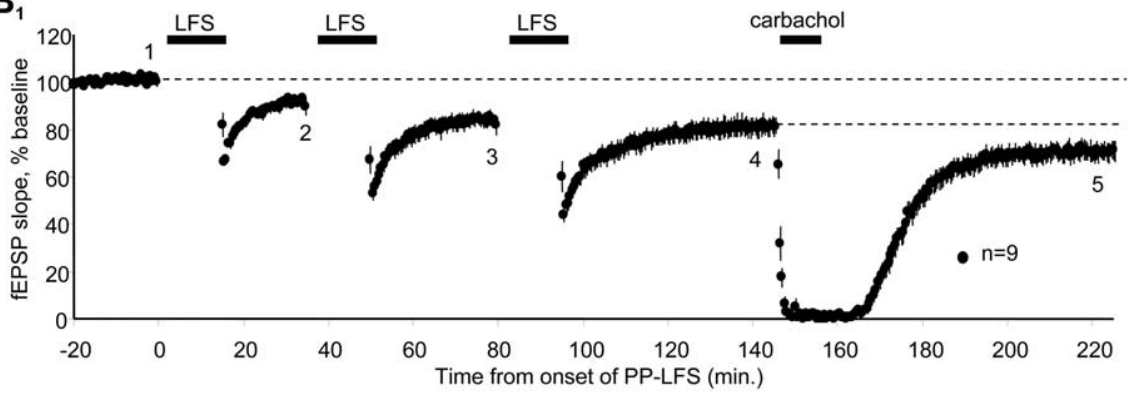

$B_{2}$
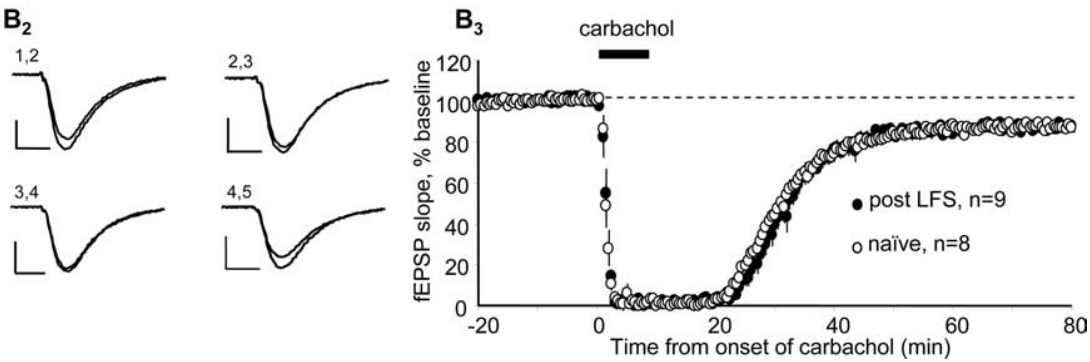

Figure 4. Saturation of synaptically induced, Gq-dependent LTD occludes CCh-induced LTD. $\boldsymbol{A}_{\boldsymbol{1}}$, Three episodes of PP-LFS (15 min) delivered to Schaffer collateral axons in the presence of D,L-AP-5 (100 $\mu \mathrm{m})$ saturated LTD (LTD after second, $70 \pm 4 \%$, and third PP-LFS, $69 \pm 4 \%$, episode were not different; $p=0.86)$. LTD induced by (Ch after saturation of PP-LFS-induced LTD is dramatically reduced. $A_{2}$, fEPSP waveforms (average of $4-6$ traces) from a representative experiment are taken at the time points indicated on the graph in $\boldsymbol{A}_{1} . \boldsymbol{A}_{3}$, Previous saturation of PP-LFS-induced LTD reduced subsequent CCh-induced LTD compared with interleaved naive control slices, which received only baseline stimulation ("post PP-LFS" replotted from 130-230 min of $\boldsymbol{A}_{\boldsymbol{1}}$; measured $1 \mathrm{~h}$ after CCh, naive, $77 \pm 2 \%$; CCh LTD after PP-LFS saturation, $93 \pm 2 \% ; p<0.001)$. $\boldsymbol{B}_{1}$, Three episodes of LFS (15 min) delivered to Schaffer collateral axons saturated LTD (LTD after second, $84 \pm 2 \%$, and third PP-LFS, $81 \pm 3 \%$, episodes were not different; $p=0.1$ ). Stimulation of mAChRs with CCh-induced normal levels of LTD after LFS saturation. $\boldsymbol{B}_{2}$, fEPSP waveforms (average of $4-6$ traces) from a representative experiment are taken at the time points indicated on the graph in $\boldsymbol{B}_{1}$. $\boldsymbol{B}_{\mathbf{3}}$, Previous saturation of LFS-induced LTD has no effect on subsequent CCh-induced LTD compared with interleaved naive control slices, which received only baseline stimulation ("post LFS" replotted from 130-230 min of $\boldsymbol{B}_{\boldsymbol{1}}$; naive, $87 \pm 1 \%$; CCh LTD after LFS saturation, $86 \pm 1 \% ; p=0.1)$

most likely function to regulate trafficking of endocytosed AMPARs.

mAChR-dependent LTD is abnormal in the mouse model of Fragile $X$ syndrome

FMRP is an RNA-binding protein that regulates dendritic protein synthesis as well as plasticity through the Gq-coupled group
1 mGluRs (Huber et al., 2002; Weiler et al., 2004; Chuang et al., 2005; Koekkoek et al., 2005; Hou et al., 2006). Loss of function mutations in FMRP in humans leads to a form of mental retardation termed Fragile $\mathrm{X}$ syndrome (Bagni and Greenough, 2005). To determine whether FMRP generally regulates $\mathrm{Gq}$ - and protein synthesisdependent synaptic plasticity, we evaluated CCh-LTD in the mouse model of FXS, Fmrl KO mice. We observed that CCh-LTD is enhanced in Fmrl KO mice compared with wild-type (WT) mice (Fig. $6 \mathrm{~A}$ ). Although the magnitude of CChinduced LTD is smaller in WT mice compared with rats (Fig. 1), it is still blocked by anisomycin (Fig. 6B). In contrast, CChLTD no longer requires protein synthesis in Fmrl KO mice (Fig. 6C,D). Gqdependent LTD induced by chemical activation of group 1 mGluRs or PP-LFS is similarly affected in Fmr1 KO mice (Fig. 6D) (Huber et al., 2002; Nosyreva and Huber, 2006) suggesting that FMRP generally acts to regulate $\mathrm{Gq}$ - and protein synthesis-dependent plasticity.

Although cholinergic stimulation is known to activate dendritic protein synthesis, the specific mRNAs that are translated are unknown (Feig and Lipton, 1993). The mRNA for FMRP is present in dendrites, where FMRP is translated in response to group 1 mGluR stimulation (Weiler et al., 1997; Antar et al., 2004). It has been hypothesized that rapid synthesis of FMRP then regulates translation of its target mRNAs such as those required for LTD (Huber et al., 2002; Bear et al., 2004; Weiler et al., 2004; Hou et al., 2006). Here, we investigated whether mAChRs stimulate the rapid synthesis of FMRP as well as FMRP target mRNA, elongation factor $1 \alpha$ $(\mathrm{EF} 1 \alpha)$ (Sung et al., 2003). Acute hippocampal slices from WT mice were treated with CCh $(50 \mu \mathrm{M} ; 10 \mathrm{~min})$ and quantitative Western blotting was performed on homogenates of CA1 for FMRP and $\mathrm{EF} 1 \alpha$. CCh stimulates a rapid (10 $\min$ ) increase in FMRP and EF1 $\alpha$ levels, which was blocked by anisomycin (Fig. $6 E)$. To determine whether FMRP is required for mAChR-dependent protein synthesis, we measured CCh-induced synthesis of EF1 $\alpha$ and that of another FMRP target and dendritic mRNA, CaMKII in CA1 of Fmrl KO mice (Burgin et al., 1990; Zalfa et al., 2003). CCh induced rapid increases in $\mathrm{EF} 1 \alpha$ and CaMKII protein in WT mice, which was not observed in Fmr1 KO littermates (Hou et al., 2006) (Fig. 6F). In support of previous studies, we observed a trend toward an increase in $\mathrm{EF} 1 \alpha$ and $\alpha$ CaMKII levels in isolated CA1 slices of Fmr1 KO mice (EF1 $\alpha$, $124 \pm 20 \%$ of WT; $p=0.27 ; \alpha$ CaMKII, $136 \pm 23 \%$ of WT; $p=$ 0.14) (Sung et al., 2003; Zalfa et al., 2003; Hou et al., 2006). These 
data demonstrate that $\mathrm{mAChRs}$ regulate translation of FMRP as well as FMRP target mRNAs. In turn, FMRP regulates mAChR induced protein synthesis and LTD. Our results suggest that Gq-coupled and protein synthesis-dependent plasticity is generally elevated and misregulated in FXS and may contribute to the cognitive deficits associated with the disease.

\section{Discussion}

Here, we demonstrate that the Gqcoupled muscarinic acetylcholine receptors activate rapid protein synthesis and induce protein synthesis-dependent LTD. Newly synthesized proteins contribute to mAChR-dependent LTD by maintaining a persistent decrease in AMPAR surface expression. Synaptic or pharmacological activation of group 1 mGluRs or $M_{1}$ mAChRs elicits protein synthesisdependent LTD, and these forms of LTD occlude each other (Figs. 1, 4) (Huber et al., 2000; Huber et al., 2001). These results indicate that different Gq-coupled receptors converge onto a common protein synthesis- dependent LTD mechanism. Data also indicate that the RNA binding protein FMRP is synthesized in response to different Gq-coupled receptors and, in turn, FMRP regulates Gq-dependent translation of FMRP target mRNAs and LTD (Fig. 6) (Weiler et al., 1997, 2004; Huber et al., 2002; Koekkoek et al., 2005;

Hou et al., 2006). We demonstrate that LTD induced through at least two different Gq-coupled receptors is abnormal in the mouse model of FXS, which suggests that strategies targeting these Gq-coupled receptors may be efficacious in treatment of FXS.

Feig and Lipton (1993) demonstrated that activation of $\mathrm{mAChRs}$ with $\mathrm{CCh}$ induced ${ }^{3} \mathrm{H}$ leucine incorporation in CA1 dendrites. Since then, little progress has been made in understanding the role of local protein synthesis in $\mathrm{mAChR}$-dependent synaptic plasticity. In neocortex, application of CCh or exogenous acetylcholine induces LTD, which is reduced by the protein synthesis inhibitor anisomycin (Massey et al., 2001; McCoy and McMahon, 2007). Importantly, in CA1, we demonstrate that pharmacological or synaptic activation of $\mathrm{M}_{1} \mathrm{mAChRs}$ (Fig. $1 B$ ) induces LTD, which relies on rapid ( $\sim 20 \mathrm{~min})$ protein synthesis from pre-existing mRNA (Figs. 1, 3) (Huber et al., 2000; Volk et al., 2006). Our findings, combined with the fact that mAChRs induce protein synthesis in CA1 dendrites, suggest that mAChRdependent LTD utilizes locally synthesized proteins from dendritic mRNA (Feig and Lipton, 1993). We also found that the major signaling pathways known to regulate translation in neurons, ERK and $\mathrm{mTOR}$, are activated by $\mathrm{mAChRs}$ and are required for mAChR-dependent LTD (Fig. 1D-F) (Dufner and Thomas, 1999; Kelleher et al., 2004b; Klann and Dever, 2004). Current evidence points to a role for ERK and MTOR in stimulation of translation initiation during induction of mGluR-LTD and NMDAR-dependent LTP through phosphorylation of eIF4E, 4E binding protein and ribosomal S6 protein (Hou and Klann, 2004; Kelleher et al., 2004b; Banko et al., 2005, 2006; Tsokas et al.,

\section{B Internal GluR1}

- Control a Carbachol
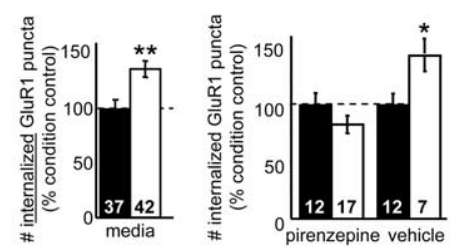

D Surface GluR1

- Control a Carbachol
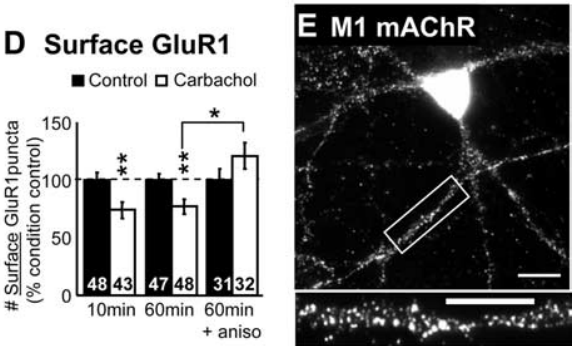

Carbachol

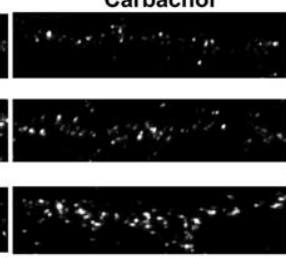

Figure 5. Activation of $M_{1}$ muscarinic acetylcholine receptors induces endocytosis and long-term, protein synthesisdependent decreases of surface $\mathrm{GluR}_{1} . A$, Representative experiment in which internalized $\mathrm{GluR}_{1}$ was labeled on live dissociated

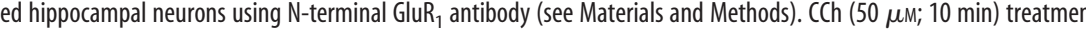
作

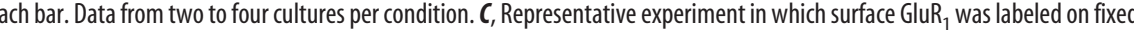
decreases at 60 min (anisomycin, $100 \pm 9 \%$; anisomycin plus $\mathrm{CCh}_{1} 121 \pm 11 \% ; p=0.2$ ). $n$ (number of cells) indicated on each bar. Data from two to four cultures per condition. ${ }^{*} p<0.05 ;{ }^{* *} p<0.01 . E, M_{1}$ mAChRs are expressed and punctate on cultured hippocampal pyramidal neurons. Scale bar, 15 and $10 \mu \mathrm{m}$.

2007). Our data imply that similar translation initiation factors are regulated by mAChRs, which lead to LTD (Fig. 7). Very recent work finds a role for ERK, but not mTOR, in CCh-induced LTD in the visual cortex suggestive of differential translational regulation by mAChRs across brain regions (McCoy and McMahon, 2007). The fact that a residual LTD persists in both rapamycin and protein synthesis inhibitors, but not in U0126, suggests an additional role for ERK. For example, ERK has recently been implicated in the capture of newly synthesized proteins required for LTD maintenance (Sajikumar et al., 2007).

Our findings are consistent with previous work in neocortex and subiculum demonstrating that mAChR-dependent LTD can occur independently of NMDARs (Kirkwood et al., 1999; Massey et al., 2001; Jo et al., 2006; McCoy and McMahon, 2007) and support the hypothesis that NMDA and Gq-coupled receptors activate distinct forms of LTD, the latter of which is regulated by protein synthesis and FMRP (Oliet et al., 1997; Huber et al., 2000, 2002). Elegant work has demonstrated that $M_{1}$ mAChRs also facilitate induction of NMDAR-dependent LTD by activation of phospholipase $\mathrm{C}$ and release of $\mathrm{Ca}^{2+}$ from intracellular stores (Choi et al., 2005; Scheiderer et al., 2006), but it is unclear whether the LTD is protein synthesis dependent under these conditions. mAChRs may facilitate the induction of both an NMDAR-dependent, protein synthesis-independent LTD and the strictly Gq and protein synthesis-dependent LTD we describe here (Marino et al., 1998; Choi et al., 2005). The extent to which either occurs may depend on experimental conditions (see Materials and Methods).

Previous work implicated mGluRs in LTD induced synapti- 

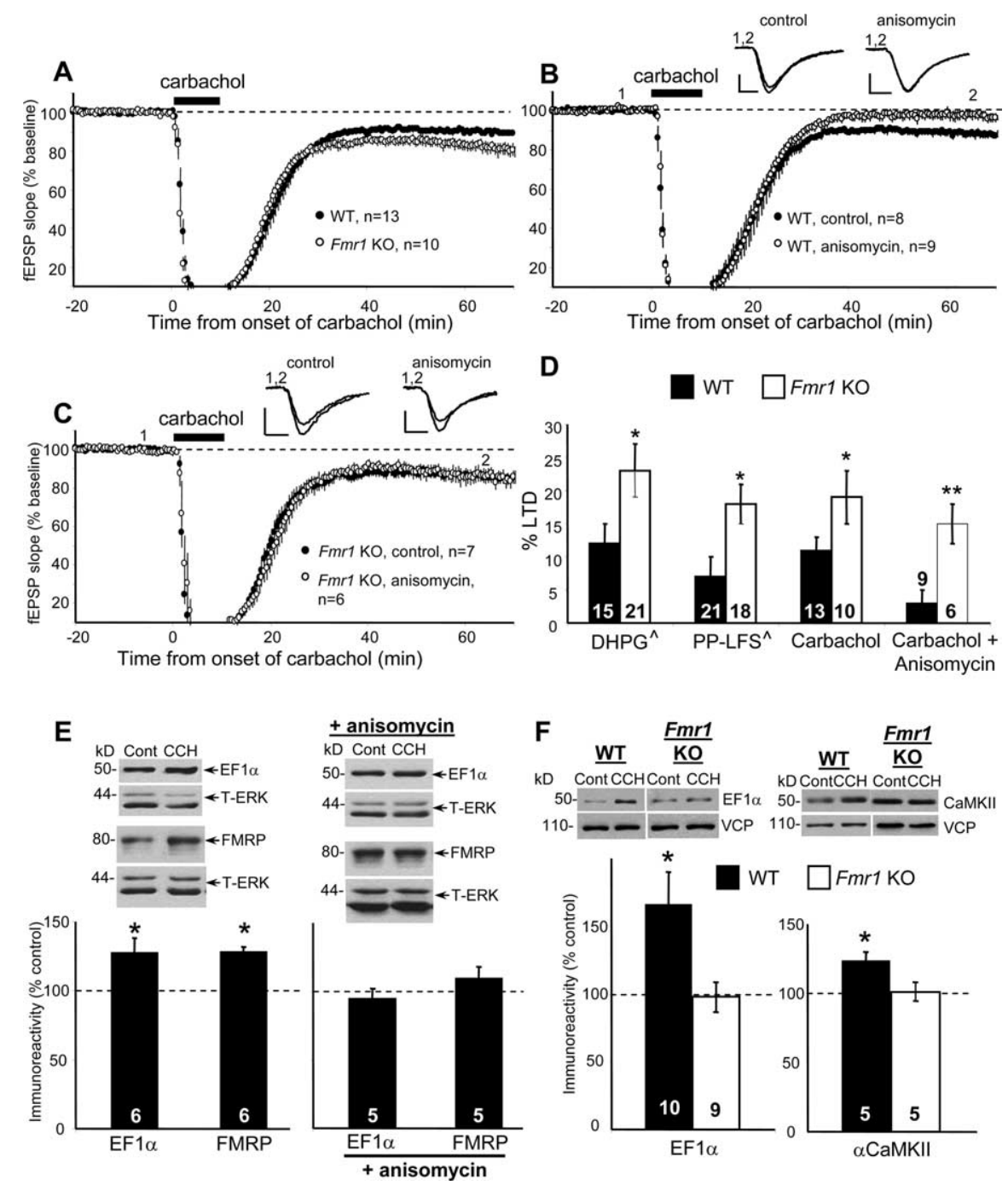

Figure 6. Muscarinic acetylcholine receptor-stimulated LTD and protein synthesis are altered in Fmr $1 \mathrm{KO}$ mice. $A, \mathrm{CCh}(50 \mu \mathrm{m}$; $10 \mathrm{~min}$ ) induced LTD is larger in magnitude in Fmr $1 \mathrm{KO}$ mice compared with interleaved experiments in WT mice (WT, $89 \pm 2 \%$; Fmr1 K0, $81 \pm 3 \% ; p=0.01)$. $\boldsymbol{B}$, As in rats, CCh-LTD is blocked by anisomycin in WT mice (WT control, $88 \pm 2 \%$; WT + anisomycin, $97 \pm 2 \% ; p<0.01$ ). C, In contrast, CCh-LTD persists in anisomycin in Fmr $1 \mathrm{KO}$ mice (Fmr $1 \mathrm{KO}$ control, $85 \pm 3 \%$; Fmr 1 KO plus anisomycin, $85 \pm 2 \% ; p=0.1$ ). D, Comparison and summary of LTD induced by chemical stimulation of group I mGluRs (DHPG) or muscarinic acetylcholine receptors (carbachol) or synaptic stimulation (PP-LFS) in WT and Fmr $1 \mathrm{~K} 0$ mice. $n$ (number of slices) is indicated on each bar. Data are replotted from the study by Huber et al. (2002). $\boldsymbol{E}$, Top, Representative Western blots demonstrating that $\mathrm{CCh}$ treatment (50 $\mu \mathrm{m} ; 10 \mathrm{~min}$ ) induces a rapid and anisomycin-sensitive increase in protein levels for EF1 $\alpha$ and FMRP in acute hippocampal slices from WT mice. Total ERK (T-ERK) levels were used as a loading control and were not changed in response to CCh. Bottom, Quantified group data (percentage control) of Western blots (EF1 $\alpha, 131 \pm 10 \%$; FMRP, $128 \pm 4 \%$; $\mathrm{EF} 1 \alpha+$ aniso, $93 \pm 8 \% ; \mathrm{FMRP}+$ aniso, $109 \pm 9 \%$ ). $n$ (number of mice) is indicated on each bar. ${ }^{*} p<0.05$, one-sample $t$ test, percentage control. $\boldsymbol{F}$, Top, Representative Western blots demonstrating that CCh treatment ( $50 \mu \mathrm{m} ; 10 \mathrm{~min}$ ) induces an increase in EF1 $\alpha$ and $\alpha$ CaMKII protein levels in acute hippocampal slices (isolated CA1) from WT but not Fmr1 K0 littermates. VCP levels were used as a loading control and were not changed in response to CCh. Bottom left, Quantified group data (percentage control) of Western blots for EF1 $\alpha$ (WT: $167 \pm 24 \%{ }^{*} p<0.05 ; \mathrm{KO}, 98 \pm 11 \% ; p=0.5$; WT vs K0: $p<0.05$ ). $n$ (number of slices) is indicated on each bar. Bottom right, Quantified group data (percentage control) of Western blots for $\alpha$ CaMKII (WT: $123 \pm 6 \%$, ${ }^{*} p<0.05 ; \mathrm{KO}: 101 \pm 6 \%, p=0.9$; WT vs K0: $p<0.05$ ).

cally with PP-LFS using the broad range mGluR antagonist LY341495 (100 $\mu \mathrm{M})$ (Kemp and Bashir, 1999; Huber et al., 2000; Volk et al., 2006). However, PP-LFS induced LTD is unaffected with selective pharmacological blockade or genetic deletion of group 1 mGluRs (Volk et al., 2006). Here, we find that coapplication of $\mathrm{M}_{1} \mathrm{mAChR}$ and group I mGluR antagonists completely blocks PP-LFS-induced LTD, indicating that both receptor types contribute to LTD, and $\mathrm{M}_{1} \mathrm{mAChRs}$ fully induce LTD in group 1 mGluR blockade (Fig. 3). This suggests that high concentrations of LY341495 may antagonize synaptic activation of $\mathrm{mAChRs}$ or interfere with $\mathrm{Gq}$ signaling. PP-LFS-induced LTD also occludes subsequent LTD induced by pharmacological activation of mAChRs or group 1 mGluRs, suggesting that these three induction methods converge on a common pathway to induce and/or express LTD (Figs. 4, 7A) (Huber et al., 2001).

Our data reveal that the newly synthesized proteins required for $\mathrm{CCh}$-induced LTD function to maintain decreases in surface AMPAR expression (Fig. 4). These results also imply that CCh-induced LTD is expressed postsynaptically, consistent with the fact that CCh-LTD does not alter paired-pulse facilitation (Scheiderer et al., 2006). Similar changes in AMPAR trafficking occur with group $1 \mathrm{mGluR}$ activation, further supporting a common expression mechanism for LTD induced by multiple Gq-coupled receptors (Snyder et al., 2001; Xiao et al., 2001; Moult et al., 2006).

The importance of the Gq- and protein synthesis-dependent LTD mechanism to cognition and cognitive disorders is underscored by our findings that both $\mathrm{mAChR}$ and $\mathrm{mGluR}$-LTD are enhanced in the mouse model of human Fragile X syndrome mental retardation, Fmr1 KO mice (Fig. 6) (Huber et al., 2002; Koekkoek et al., 2005; Hou et al., 2006; Nosyreva and Huber, 2006). These results indicate that the defect in Fmr1 KO mice may lie downstream of mGluRs, within the Gq or translational regulatory pathways. Related to this idea, there is a report of abnormal $\mathrm{mAChR}$ regulation of GABA release in Fmr1 KO mice, suggesting that other aspects of $\mathrm{mAChR}$ function are altered (D'Antuono et al., 2003). We also present evidence that mAChRs induce rapid translation of FMRP target mRNAs, which are expressed dendritically and are known to be synthesized in response to mGluRs, such as FMRP, EF1 $\alpha$, and CaMKII (Burgin et al., 1990; Weiler et al., 1997; Sung et al., 2003; Zalfa et al., 2003; Antar et al., 2004; Huang et al., 2005; Hou et al., 2006). FMRP is an RNA-binding protein and regulates translation of its mRNA targets, including itself and EF1 $\alpha$ (Garber et al., 2006). In support of this idea, we find that mAChR induced synthesis of EF1 $\alpha$ and CaMKII are absent in Fmr1 KO mice (Fig. $6 E$ ), similar to mGluR-induced synthesis, suggesting that FMRP is a common regulator of Gq-dependent protein synthesis and/or Gq signaling to translation machinery is generally affected in Fmr1 KO mice (Weiler et al., 2004; Hou et al., 2006). We hypothesize that the observation of enhanced Gq-dependent LTD in Fmrl KO mice despite the absence of mGluR and mAChR- 
dependent protein synthesis stems from the loss of FMRP-mediated translational suppression, which leads to a steady state elevation of "LTD proteins" and protein synthesis independent LTD in the Fmr1 KO mice (Figs. 6, 7B) (Zalfa et al., 2003; Hou et al., 2006).

Recent evidence indicates that mGluRdependent plasticity may be generally enhanced in multiple brain regions of Fmr1 KO mice (Huber et al., 2002; Chuang et al., 2005; Koekkoek et al., 2005; Nosyreva and Huber, 2006). Consequently, mGluR antagonists have been suggested to reverse some phenotypes of FXS (Bear et al., 2004; Bear, 2005) for which there is experimental support in animal models (McBride et al., 2005; Yan et al., 2005; Tucker et al., 2006). Both a deficit and elevation of hippocampal cholinergic activity is associated with learning and memory deficits in rodents, suggesting that a critical range of cholinergic activity is required for optimal hippocampal function (Bunce et al., 2004a,b; Elvander et al., 2004) (for review, see Hasselmo, 2006). Therefore, antagonism of $M_{1}$ mAChRs may actually facilitate cognitive function in FXS, alone or in combination with group 1 mGluR antagonists.

Here, we demonstrated that cholinergic and glutamatergic Gq-coupled receptors activate a common, protein synthesis-dependent LTD mechanism. An interesting possibility is that other Gq-coupled receptors known to induce LTD in CA1, such as $\alpha 1$ adrenergic and 5- $\mathrm{HT}_{2}$ receptors, do so through the same mechanism (Scheiderer et al., 2004; Choi et al., 2005). In vivo, Gq-dependent LTD may be induced by moderate, coincident, activation of multiple Gq-coupled receptors (Fig. 3A-D). Septohippocampal inputs may facilitate memory during arousal or emotional states through modulation of Gq-dependent LTD (McGaugh, 2004). In support of this idea, the magnitude of hippocampal Gq-dependent LTD is positively correlated with spatial memory performance in aged rats (Lee et al., 2005) and loss of hippocampal cholinergic input, such that occurs in Alzheimer's disease, leads to deficits in hippocampaldependent memory and mAChR dependent LTD (Kesner et al., 1989; Scheiderer et al., 2006). Elucidation of Gq- and protein synthesis-dependent LTD mechanisms will contribute to our understanding of how extrahippocampal neuromodulatory systems contribute to memory and cognitive disorders.

\section{References}

Anagnostaras SG, Murphy GG, Hamilton SE, Mitchell SL, Rahnama NP, Nathanson NM, Silva AJ (2003) Selective cognitive dysfunction in acetylcholine M1 muscarinic receptor mutant mice. Nat Neurosci 6:51-58.

Antar LN, Afroz R, Dictenberg JB, Carroll RC, Bassell GJ (2004) Metabotropic glutamate receptor activation regulates fragile $\mathrm{x}$ mental retardation protein and FMR1 mRNA localization differentially in dendrites and at synapses. J Neurosci 24:2648-2655.

Bagni C, Greenough WT (2005) From mRNP trafficking to spine dysmorphogenesis: the roots of fragile X syndrome. Nat Rev Neurosci 6:376-387.

Banko JL, Poulin F, Hou L, DeMaria CT, Sonenberg N, Klann E (2005) The translation repressor 4E-BP2 is critical for eIF4F complex formation, syn-
B Fmr1 KO
PP-LFS

ptic stimulation)

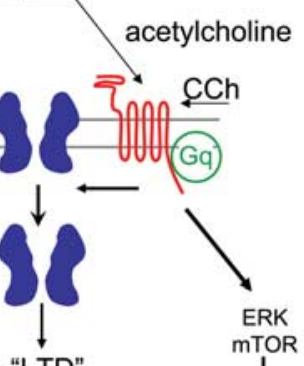

"LTD"

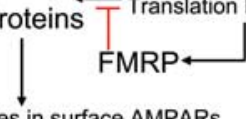

LTD

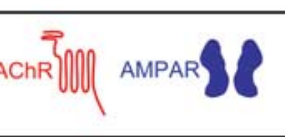

PP-LFS

(synaptic stimulation)

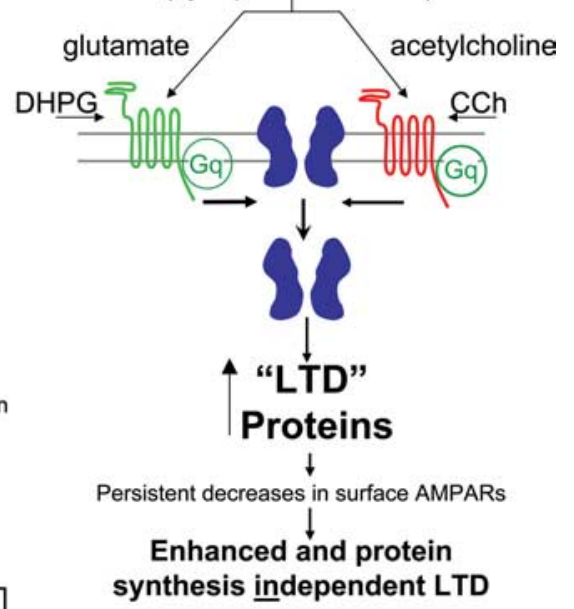

Figure 7. Working model of Gq-dependent LTD in wild-type rodents and Fmr $1 \mathrm{KO}$ mice. $\boldsymbol{A}$, In wild-type rodents, paired pulses of low frequency electrical stimulation (PP-LFS) to Schaffer collateral axons activates both group $1 \mathrm{mGluRs}^{(} \mathrm{mGluR}_{1}$ and $m G$ luR $R_{5}$ )

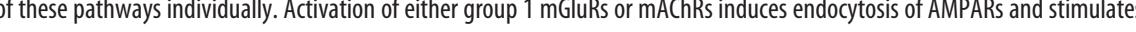
of FMRP, there is a loss of translational suppression and increased steady state level of LTD proteins, which leads to enhanced LTD and AMPAR surface decreases that does not require protein synthesis.

aptic plasticity, and memory in the hippocampus. J Neurosci 25:9581-9590.

Banko JL, Hou L, Poulin F, Sonenberg N, Klann E (2006) Regulation of eukaryotic initiation factor $4 \mathrm{E}$ by converging signaling pathways during metabotropic glutamate receptor-dependent long-term depression. J Neurosci 26:2167-2173.

Bear MF (2005) Therapeutic implications of the mGluR theory of fragile X mental retardation. Genes Brain Behav 4:393-398.

Bear MF, Huber KM, Warren ST (2004) The mGluR theory of fragile X mental retardation. Trends Neurosci 27:370-377.

Benardo LS, Prince DA (1982) Cholinergic excitation of mammalian hippocampal pyramidal cells. Brain Res 249:315-331.

Berkeley JL, Gomeza J, Wess J, Hamilton SE, Nathanson NM, Levey AI (2001) M1 muscarinic acetylcholine receptors activate extracellular signal-regulated kinase in CA1 pyramidal neurons in mouse hippocampal slices. Mol Cell Neurosci 18:512-524.

Bolshakov VY, Siegelbaum SA (1994) Postsynaptic induction and presynaptic expression of hippocampal long-term depression. Science 264:1148-1152.

Brewer GJ, Torricelli JR, Evege EK, Price PJ (1993) Optimized survival of hippocampal neurons in B27-supplemented Neurobasal, a new serumfree medium combination. J Neurosci Res 35:567-576.

Bunce JG, Sabolek HR, Chrobak JJ (2004a) Timing of administration mediates the memory effects of intraseptal carbachol infusion. Neuroscience 127:593-600.

Bunce JG, Sabolek HR, Chrobak JJ (2004b) Intraseptal infusion of the cholinergic agonist carbachol impairs delayed-non-match-to-sample radial arm maze performance in the rat. Hippocampus 14:450-459.

Burgin KE, Waxham MN, Rickling S, Westgate SA, Mobley WC, Kelly PT (1990) In situ hybridization histochemistry of $\mathrm{Ca}^{2+} /$ calmodulindependent protein kinase in developing rat brain. J Neurosci 10:1788-1798.

Caccamo A, Oddo S, Billings LM, Green KN, Martinez-Coria H, Fisher A, 
LaFerla FM (2006) M1 receptors play a central role in modulating ADlike pathology in transgenic mice. Neuron 49:671-682.

Choi SY, Chang J, Jiang B, Seol GH, Min SS, Han JS, Shin HS, Gallagher M, Kirkwood A (2005) Multiple receptors coupled to phospholipase C gate long-term depression in visual cortex. J Neurosci 25:11433-11443.

Chuang SC, Zhao W, Bauchwitz R, Yan Q, Bianchi R, Wong RK (2005) Prolonged epileptiform discharges induced by altered group I metabotropic glutamate receptor-mediated synaptic responses in hippocampal slices of a fragile X mouse model. J Neurosci 25:8048-8055.

Cole AE, Nicoll RA (1983) Acetylcholine mediates a slow synaptic potential in hippocampal pyramidal cells. Science 221:1299-1301.

D'Antuono M, Merlo D, Avoli M (2003) Involvement of cholinergic and GABAergic systems in the fragile $\mathrm{X}$ knockout mice. Neuroscience 119:9-13.

Dorje F, Wess J, Lambrecht G, Tacke R, Mutschler E, Brann MR (1991) Antagonist binding profiles of five cloned human muscarinic receptor subtypes. J Pharmacol Exp Ther 256:727-733.

Dudek SM, Bear MF (1992) Homosynaptic long-term depression in area CA1 of hippocampus and effects of $N$-methyl-D-aspartate receptor blockade. Proc Natl Acad Sci USA 89:4363-4367.

Dufner A, Thomas G (1999) Ribosomal S6 kinase signaling and the control of translation. Exp Cell Res 253:100-109.

Dutar P, Nicoll RA (1988) Classification of muscarinic responses in hippocampus in terms of receptor subtypes and second-messenger systems: electrophysiological studies in vitro. J Neurosci 8:4214-4224.

Elvander E, Schott PA, Sandin J, Bjelke B, Kehr J, Yoshitake T, Ogren SO (2004) Intraseptal muscarinic ligands and galanin: influence on hippocampal acetylcholine and cognition. Neuroscience 126:541-557.

Feig S, Lipton P (1993) Pairing the cholinergic agonist carbachol with patterned Schaffer collateral stimulation initiates protein synthesis in hippocampal CA1 pyramidal cell dendrites via a muscarinic, NMDAdependent mechanism. J Neurosci 13:1010-1021.

Fitzjohn SM, Kingston AE, Lodge D, Collingridge GL (1999) DHPGinduced LTD in area CA1 of juvenile rat hippocampus; characterisation and sensitivity to novel mGlu receptor antagonists. Neuropharmacology 38:1577-1583.

Fitzjohn SM, Palmer MJ, May JE, Neeson A, Morris SA, Collingridge GL (2001) A characterisation of long-term depression induced by metabotropic glutamate receptor activation in the rat hippocampus in vitro. J Physiol (Lond) 537:421-430.

Frotscher M, Schlander M, Leranth C (1986) Cholinergic neurons in the hippocampus. A combined light- and electron-microscopic immunocytochemical study in the rat. Cell Tissue Res 246:293-301.

Gallagher SM, Daly CA, Bear MF, Huber KM (2004) Extracellular signalregulated protein kinase activation is required for metabotropic glutamate receptor-dependent long-term depression in hippocampal area CA1. J Neurosci 24:4859-4864.

Garber K, Smith KT, Reines D, Warren ST (2006) Transcription, translation and fragile X syndrome. Curr Opin Genet Dev 16:270-275.

Gibson JR, Bartley AF, Huber KM (2006) Role for the subthreshold currents ILeak and IH in the homeostatic control of excitability in neocortical somatostatin-positive inhibitory neurons. J Neurophysiol 96:420-432.

Hasselmo ME (2006) The role of acetylcholine in learning and memory. Curr Opin Neurobiol 16:710-715.

Hou L, Klann E (2004) Activation of the phosphoinositide 3-kinase-Aktmammalian target of rapamycin signaling pathway is required for metabotropic glutamate receptor-dependent long-term depression. J Neurosci 24:6352-6361.

Hou L, Antion MD, Hu D, Spencer CM, Paylor R, Klann E (2006) Dynamic translational and proteasomal regulation of fragile $\mathrm{X}$ mental retardation protein controls mGluR-dependent long-term depression. Neuron 51:441-454.

Huang F, Chotiner JK, Steward O (2005) The mRNA for elongation factor $1 \alpha$ is localized in dendrites and translated in response to treatments that induce long-term depression. J Neurosci 25:7199-7209.

Huber KM, Kayser MS, Bear MF (2000) Role for rapid dendritic protein synthesis in hippocampal mGluR-dependent LTD. Science 288:1254-1257.

Huber KM, Roder JC, Bear MF (2001) Chemical induction of mGluR5- and protein synthesis-dependent long-term depression in hippocampal area CA1. J Neurophysiol 86:321-325.

Huber KM, Gallagher SM, Warren ST, Bear MF (2002) Altered synaptic plasticity in a mouse model of fragile-X mental retardation. Proc Natl Acad Sci USA 99:7746-7750.

Jo J, Ball SM, Seok H, Oh SB, Massey PV, Molnar E, Bashir ZI, Cho K (2006) Experience-dependent modification of mechanisms of long-term depression. Nat Neurosci 9:170-172.

Kelleher III RJ, Govindarajan A, Tonegawa S (2004a) Translational regulatory mechanisms in persistent forms of synaptic plasticity. Neuron 44:59-73

Kelleher III RJ, Govindarajan A, Jung HY, Kang H, Tonegawa S (2004b) Translational control by MAPK signaling in long-term synaptic plasticity and memory. Cell 116:467-479.

Kemp N, Bashir ZI (1999) Induction of LTD in the adult hippocampus by the synaptic activation of AMPA/kainate and metabotropic glutamate receptors. Neuropharmacology 38:495-504.

Kesner RP, Adelstein TB, Crutcher KA (1989) Equivalent spatial location memory deficits in rats with medial septum or hippocampal formation lesions and patients with dementia of the Alzheimer's type. Brain Cogn 9:289-300.

Kirkwood A, Rozas C, Kirkwood J, Perez F, Bear MF (1999) Modulation of long-term synaptic depression in visual cortex by acetylcholine and norepinephrine. J Neurosci 19:1599-1609.

Klann E, Dever TE (2004) Biochemical mechanisms for translational regulation in synaptic plasticity. Nat Rev Neurosci 5:931-942.

Kleppisch T, Voigt V, Allmann R, Offermanns S (2001) G( $\alpha$ )q-deficient mice lack metabotropic glutamate receptor-dependent long-term depression but show normal long-term potentiation in the hippocampal CA1 region. J Neurosci 21:4943-4948.

Koekkoek SK et al (2005) Deletion of FMR1 in Purkinje cells enhances parallel fiber LTD, enlarges spines, and attenuates cerebellar eyelid conditioning in Fragile X syndrome. Neuron 47:339-352.

Lee HK, Min SS, Gallagher M, Kirkwood A (2005) NMDA receptorindependent long-term depression correlates with successful aging in rats. Nat Neurosci 8:1657-1659.

Marino MJ, Rouse ST, Levey AI, Potter LT, Conn PJ (1998) Activation of the genetically defined $\mathrm{ml}$ muscarinic receptor potentiates $\mathrm{N}$-methyl-Daspartate (NMDA) receptor currents in hippocampal pyramidal cells. Proc Natl Acad Sci USA 95:11465-11470.

Massey PV, Bhabra G, Cho K, Brown MW, Bashir ZI (2001) Activation of muscarinic receptors induces protein synthesis-dependent long-lasting depression in the perirhinal cortex. Eur J Neurosci 14:145-152.

McBride SM, Choi CH, Wang Y, Liebelt D, Braunstein E, Ferreiro D, Sehgal A, Siwicki KK, Dockendorff TC, Nguyen HT, McDonald TV, Jongens TA (2005) Pharmacological rescue of synaptic plasticity, courtship behavior, and mushroom body defects in a Drosophila model of fragile X syndrome. Neuron 45:753-764.

McCoy PA, McMahon LL (2007) Muscarinic receptor dependent long term depression in rat visual cortex is PKC independent but requires ERK1/2 activation and protein synthesis. J Neurophysiol, in press.

McGaugh JL (2004) The amygdala modulates the consolidation of memories of emotionally arousing experiences. Annu Rev Neurosci 27:1-28.

Moult PR, Gladding CM, Sanderson TM, Fitzjohn SM, Bashir ZI, Molnar E, Collingridge GL (2006) Tyrosine phosphatases regulate AMPA receptor trafficking during metabotropic glutamate receptor-mediated long-term depression. J Neurosci 26:2544-2554.

Nosyreva ED, Huber KM (2005) Developmental switch in synaptic mechanisms of hippocampal metabotropic glutamate receptor-dependent longterm depression. J Neurosci 25:2992-3001.

Nosyreva ED, Huber KM (2006) Metabotropic receptor-dependent longterm depression persists in the absence of protein synthesis in the mouse model of fragile x syndrome. J Neurophysiol 95:3291-3295.

Oliet SH, Malenka RC, Nicoll RA (1997) Two distinct forms of long-term depression coexist in CA1 hippocampal pyramidal cells. Neuron 18:969-982.

Palmer MJ, Irving AJ, Seabrook GR, Jane DE, Collingridge GL (1997) The group I mGlu receptor agonist DHPG induces a novel form of LTD in the CA1 region of the hippocampus. Neuropharmacology 36:1517-1532.

Roberson ED, English JD, Adams JP, Selcher JC, Kondratick C, Sweatt JD (1999) The mitogen-activated protein kinase cascade couples PKA and $\mathrm{PKC}$ to cAMP response element binding protein phosphorylation in area CA1 of hippocampus. J Neurosci 19:4337-4348.

Rosenblum K, Futter M, Jones M, Hulme EC, Bliss TV (2000) ERKI/II reg- 
ulation by the muscarinic acetylcholine receptors in neurons. J Neurosci 20:977-985.

Sajikumar S, Navakkode S, Frey JU (2007) Identification of compartmentand process-specific molecules required for "synaptic tagging" during long-term potentiation and long-term depression in hippocampal CA1. J Neurosci 27:5068-5080.

Schafer MK, Eiden LE, Weihe E (1998) Cholinergic neurons and terminal fields revealed by immunohistochemistry for the vesicular acetylcholine transporter. I. Central nervous system. Neuroscience 84:331-359.

Scheiderer CL, Dobrunz LE, McMahon LL (2004) Novel form of long-term synaptic depression in rat hippocampus induced by activation of alpha 1 adrenergic receptors. J Neurophysiol 91:1071-1077.

Scheiderer CL, McCutchen E, Thacker EE, Kolasa K, Ward MK, Parsons D, Harrell LE, Dobrunz LE, McMahon LL (2006) Sympathetic sprouting drives hippocampal cholinergic reinnervation that prevents loss of a muscarinic receptor-dependent long-term depression at CA3-CA1 synapses. J Neurosci 26:3745-3756.

Shinoe T, Matsui M, Taketo MM, Manabe T (2005) Modulation of synaptic plasticity by physiological activation of $\mathrm{M}_{1}$ muscarinic acetylcholine receptors in the mouse hippocampus. J Neurosci 25:11194-11200.

Snyder EM, Philpot BD, Huber KM, Dong X, Fallon JR, Bear MF (2001) Internalization of ionotropic glutamate receptors in response to mGluR activation. Nat Neurosci 4:1079-1085.

Sung YJ, Dolzhanskaya N, Nolin SL, Brown T, Currie JR, Denman RB (2003) The fragile $\mathrm{X}$ mental retardation protein FMRP binds elongation factor $1 \mathrm{~A}$ mRNA and negatively regulates its translation in vivo. J Biol Chem 278:15669-15678.

Tsokas P, Ma T, Iyengar R, Landau EM, Blitzer RD (2007) Mitogen- activated protein kinase upregulates the dendritic translation machinery in long-term potentiation by controlling the mammalian target of rapamycin pathway. J Neurosci 27:5885-5894.

Tucker B, Richards RI, Lardelli M (2006) Contribution of mGluR and Fmr1 functional pathways to neurite morphogenesis, craniofacial development and fragile X syndrome. Hum Mol Genet 15:3446-3458.

Volk LJ, Daly CA, Huber KM (2006) Differential roles for group $1 \mathrm{mGluR}$ subtypes in induction and expression of chemically induced hippocampal long-term depression. J Neurophysiol 95:2427-2438.

Weiler IJ, Irwin SA, Klintsova AY, Spencer CM, Brazelton AD, Miyashiro K, Comery TA, Patel B, Eberwine J, Greenough WT (1997) Fragile X mental retardation protein is translated near synapses in response to neurotransmitter activation. Proc Natl Acad Sci USA 94:5395-5400.

Weiler IJ, Spangler CC, Klintsova AY, Grossman AW, Kim SH, BertainaAnglade V, Khaliq H, de Vries FE, Lambers FA, Hatia F, Base CK, Greenough WT (2004) Fragile X mental retardation protein is necessary for neurotransmitter-activated protein translation at synapses. Proc Natl Acad Sci USA 101:17504-17509.

Xiao MY, Zhou Q, Nicoll RA (2001) Metabotropic glutamate receptor activation causes a rapid redistribution of AMPA receptors. Neuropharmacology 41:664-671.

Yan QJ, Rammal M, Tranfaglia M, Bauchwitz RP (2005) Suppression of two major Fragile X Syndrome mouse model phenotypes by the mGluR5 antagonist MPEP. Neuropharmacology 49:1053-1066.

Zalfa F, Giorgi M, Primerano B, Moro A, Di Penta A, Reis S, Oostra B, Bagni C (2003) The fragile X syndrome protein FMRP associates with BCl RNA and regulates the translation of specific mRNAs at synapses. Cell 112:317-327. 